TRILOGI: Jurnal Penelitian Ilmu Sosial dan Eksakta Volume: 1, Nomor 1, 2021, Hal: 47-63

\title{
Faktor-faktor yang Memengaruhi Niat Pembelian Produk Pangan Organik : Sebuah Studi Literatur
}

\author{
Risa Martha Muliasari ${ }^{1}$, Anisa Nurina Aulia ${ }^{1}$, Andika Putra Setiawan ${ }^{1}$, Indah Ibanah $^{2}$ \\ 1Universitas Muhammadiyah Jember; "risa.m.muliasari@unmuhjember.ac.id, anisa_nurina@unmuhjember.ac.id, \\ andikaputra@unmuhjember.ac.id \\ 2Universitas Jember; indahibanah.faperta@unej.ac.id
}

\begin{abstract}
Abstrak: Pasar produk pangan organik mulai tumbuh selama pandemi covid-19. Jumlah produsen juga ikut tumbuh karena dianggap menguntungkan dan menjadi peluang bagi produsen baru untuk ikut mencoba menyediakan produk pangan organik. Tujuan penelitian ini adalah menyintesis temuan-temuan tentang faktor-faktor yang meDOI: https://doi.org/10.47134/trilogi.v1i1.11

${ }^{*}$ Correspondensi: Risa Martha Muliasari Email: risa.m.muliasari@unmuhjember.ac.id

Received: 27 September 2021

Accepted: 29 September 2021

Published: 30 September 2021 mengaruhi niat pembelian produk pangan organik. Data diperoleh dari studi literatur jurnal nasional dan internasional sejumlah dua puluh delapan jurnal yang relevan dengan judul. Faktor-faktor yang umumnya memengaruhi niat pembelian produk pangan organik terdiri atas harga, motivasi sehat, karakteristik produk, sikap, distribusi, kepedulian pada lingkungan dan norma subjektif.
\end{abstract}

Kata kunci: faktor pembelian, pangan organic, studi literatur.

Copyright: () 2021 by the authors. Submitted

Abstrak: Organic food products market began to grow during the COVID-19 pandemic. Number of producers also grow because it is considered profitable and became an opportunity for new producers to try providing organic food products. for possible open access publication under th terms and conditions of the Creative Commons Attribution (CC BY) license (http://creativecommons.org/licenses/by/4.0/).

The aim of this study was to synthesize findings about determinants of intention to purchase organic food products. Literature study from eighteen relevant national and international journals are applied to get the data. Generally determinants of intention to purchase organic food products consist price, healthy motivation, product characteristics, attitude, distribution, environmental concern and subjective norms.

Keywords: literature study, organic foods, purchasing determinant.

\section{Pendahuluan}

Pangan merupakan kebutuhan yang harus dipenuhi setiap hari dan termasuk konsumsi otonomus. Pangan organik menjadi salah satu alternatif selama pandemi covid-19. Permintaan pangan organik meningkat karena masyarakat menjaga daya tahan tubuh dengan menerapkan pola hidup sehat (Pusat Sosial Ekonomi dan Kebijakan Pertanian, 2020). Pola hidup sehat yang berkelanjutan akan mendorong pertumbuhan pasar produk pangan organik. Ketika pasar mulai tumbuh, jumlah produsen juga ikut tumbuh karena dianggap menguntungkan dan peluang bagi produsen baru untuk ikut mencoba menyediakan produk pangan organik.

Produk pangan organik memiliki lebih banyak manfaat dibandingkan pangan konvensional. Selain lebih sehat bagi tubuh, pangan organik juga ramah lingkungan. Pertanian konvensional yang mengutamakan penggunaan pupuk kimiawi dan pestisida menyebabkan kerusakan pada sifat biologi, kimia dan fisik tanah dalam jangka panjang 
sehingga menjadi lahan kritis dan marginal. Konsumsi produk organik yang berkelanjutan akan berkontribusi pada kesuksesan program GERMAS (Gerakan Masyarakat Hidup Sehat) dan penurunan gangguan kesehatan. Pengembangan pertanian organik di beberapa negara seperti Amerika Serikat, Korea Selatan, Taiwan dan Jepang mengalami kemajuan pesat karena buah dan sayur segar yang ditanam dengan sistem pertanian organik mempunyai tekstur, aroma, warna, rasa yang lebih baik daripada pertanian konvensional (Balai Pengkajian Teknologi Pertanian Sulawesi Utara, 2016).

Tujuan penelitian ini adalah menyintesis temuan-temuan tentang faktor-faktor yang memengaruhi niat pembelian produk pangan organik. Hasil penelitian diharapkan dapat dijadikan sebagai bahan pertimbangan dalam mempertahankan pembelian konsumen dan pengembangan pasar.

\section{Metode}

Penelitian ini studi literatur dari jurnal nasional dan internasional sejumlah dua puluh delapan jurnal yang relevan dengan judul. Beragam literatur sejenis dibandingkan dan disintesis agar menghasilkan kesimpulan.

\section{Hasil dan Pembahasan}

\section{Produk Pangan Organik}

Pertanian organik tidak menggunakan input sintetis, namun memanfaatkan sumber-sumber daya alam secara berkelanjutan (Syukur \& Melati, 2016). Pangan organik berasal dari suatu lahan yang dikelola dengan tujuan untuk memelihara ekosistem dalam mencapai produktivitas yang berkelanjutan, melakukan pengendalian penyakit, hama dan gulma, melalui beberapa cara seperti daur ulang sisa ternak dan tumbuhan, penggunaan bahan hayati (pangan), pengolahan lahan dan penanaman, pengelolaan air, serta seleksi dan pergiliran tanaman (Peraturan Menteri Pertanian Nomor 64/Permentan/OT.140/5/2013 tentang Sistem Pertanian Organik, Pasal 1 Ayat 3).

Istilah pangan organik mungkin memiliki perbedaan arti berdasarkan sudut pandang penulis dan konteks atau cakupan. Pangan organik berupa beras didefinisikan sebagai pangan alami dan diproduksi tanpa pupuk kimia, tanpa pestisida, tanpa bahan-bahan kimia lainnya, tanpa antibiotik atau hormon dan tidak berbahaya bagi hewan (Jitrawang \& Krairit, 2019). Ada juga yang menambahkan bebas GMO untuk mendefinisikan produk organik (David \& Ardiansyah, 2017). Indonesia telah menetapkan bahwa Logo Organik Indonesia harus dicantumkan pada semua produk organik yang telah disertifikasi dan beredar di Indonesia baik produksi dalam negeri ataupun pemasukan (Syukur \& Melati, 2016). 


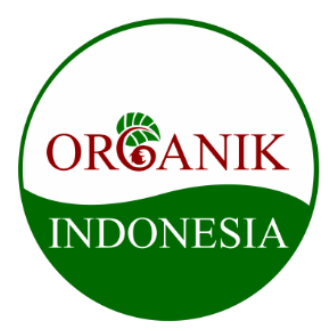

Gambar 1. Logo Organik Indonesia

Sayuran yang dapat dibudidayakan secara organik meliputi kelompok sayuran daun, sayuran buah, sayuran bunga, sayuran umbi dan sayuran batang. Pengelompokan ini didasarkan pada bagian yang dikonsumsi. Sayuran daun yang sering dibudidayakan secara organik adalah bayam hijau, bayam merah, bawang daun, caisim, daun singkong, kangkung, kalian, kol, pakcoy, petsay, sawi putih, selada keriting, selada head, seledri. Sayuran buah yang sering dibudidayakan secara organik adalah baby corn, buncis, cabai, jagung manis, kacang merah, kacang kapri, kecipir, labu parang, labu siap, mentimun, paria, terong, tomat dan zukini. Sayuran bunga yang sering dibudidayakan secara organik adalah brokoli dan kembang kol. Sayuran umbi yang sering dibudidayakan secara organik adalah bit merah, kentang, lobak dan wortel. Sayuran batang yang sering dibudidayakan secara organik adalah asparagus (Syukur \& Melati, 2016).

Tabel 1. Sayuran Organik

\begin{tabular}{|c|c|}
\hline Kelompok Sayuran & Nama Sayuran \\
\hline Sayuran daun & $\begin{array}{l}\text { Bayam hijau, bayam merah, bawang daun, caisim, daun } \\
\text { singkong, kangkung, kalian, kol, pakcoy, petsay, sawi putih, } \\
\text { selada keriting, selada head, seledri }\end{array}$ \\
\hline Sayuran buah & $\begin{array}{l}\text { Baby corn, buncis, cabai, jagung manis, kacang merah, kacang } \\
\text { kapri, kecipir, labu parang, labu siap, mentimun, paria, terong, } \\
\text { tomat dan zukini }\end{array}$ \\
\hline Sayuran bunga & Brokoli dan kembang kol \\
\hline Sayuran umbi & Bit merah, kentang, lobak dan wortel \\
\hline Sayuran batang & Asparagus \\
\hline
\end{tabular}

Sumber: Syukur \& Melati, 2016

Standar budidaya yang digunakan pada sayuran organik berdasarkan SNI 6729:2013 (Permentan No. 64/Permentan/OT.140/5/2013) adalah:

1. Lahan bekas pertanian konvensional harus mengalami periode konversi paling sedikit 2 (dua) tahun sebelum penebaran benih, paling sedikit 3 (tiga) tahun sebelum panen hasil pertama produk organik atau paling sedikit 12 (dua belas) bulan untuk kasus tertentu. Dalam hal seluruh lahan tidak dapat dikonversi secara bersamaan, maka boleh dikerjakan secara bertahap. Tidak menyiapkan lahan dengan cara pembakaran, termasuk pembakaran sampah.

2. Benih harus berasal dari tumbuhan yang ditumbuhkan secara organik dan tidak berasal dari hasil rekayasa genetika tanaman. 
3. Sumber air berasal dari sumber mata air yang langsung atau dari sumber lain yang tidak terkontaminasi oleh bahan kimia sintetis dan cemaran lain yang membahayakan.

4. Pengelolaan Kesuburan Tanah: memelihara dan meningkatkan kesuburan dan aktivitas biologis tanah dengan cara penanaman kacang-kacangan (leguminoceae), pupuk hijau atau tanaman berakar dalam melalui program rotasi tahunan yang sesuai. Bahan organik dicampur ke dalam tanah baik dalam bentuk kompos maupun segar dari unit usaha budidaya. Produk samping peternakan, seperti kotoran ternak, boleh digunakan apabila berasal dari peternakan yang dibudidayakan secara organik. Untuk aktivasi kompos dapat menggunakan mikroorganisme atau bahan lain yang berbasis tanaman yang sesuai.

5. Pengendalian organisme pengganggu tanaman dan pemeliharaan tanaman meliputi hal-hal berikut ini: tidak menggunakan bahan kimia sintetis dan organisme atau produk hasil rekayasa genetika, tidak melakukan proses pembakaran dalam pengendalian gulma, dan menerapkan sistem pengendalian hama dan penyakit yang terpadu sehingga dapat menekan kerugian akibat organisme pengganggu tanaman.

6. Penanganan pascapanen, penyimpanan, dan transportasi meliputi hal-hal berikut ini: (a) Pencucian produk organik segar dilakukan dengan menggunakan air standar baku yang diizinkan untuk sistem pertanian organik, (b) Tidak mencampur produk organik dengan produk non organik dalam penanganan pascapanen termasuk dalam pengolahan, penyimpanan, dan transportasi, (c) Tidak menggunakan bahan kimia sintetis dalam proses penanganan pascapanen, penyimpanan, maupun pengangkutan, (d) Peralatan pascapanen harus bebas kontaminasi bahan kimia sintetis, (e) tidak menggunakan bahan pembungkus yang menimbulkan kontaminasi produk, (f) Dalam pengemasan disarankan menggunakan bahan yang dapat didaur ulang atau digunakan kembali atau menggunakan bahan yang mudah mengalami dekomposisi. Selalu menjaga integritas produk organik selama penanganan, penyimpanan,dan transportasi, (g) Jika hanya sebagian produk yang disertifikasi, maka produk lainnya harus disimpan dan ditangani secara terpisah dan kedua jenis produk ini harus dapat diidentifikasikan secara jelas, (h) Penyimpanan produk organik harus dipisahkan dari produk konvensional serta harus secara jelas dicantumkan pada label, (i) Tempat penyimpanan dan kontainer untuk pengangkutan produk organik segar harus dibersihkan dahulu dengan menggunakan metode dan bahan yang boleh digunakan. Jika tempat penyimpanan atau kontainer yang digunakan tidak hanya digunakan untuk produk organik, maka harus dilakukan tindakan pengamanan agar produk organik tidak terkontaminasi oleh produk non organik.

Selain sayuran, tanaman pangan yang umum dibudidayakan secara organik adalah beras. Penyiapan lahan yang ideal untuk sawah organik harus dilakukan beberapa kali (dua sampai tiga kali). Pengolahan tanah pertama adalah pembajakan pada lahan yang telah ditumbuhi tanaman penutup ataupun sisa-sisa jerami padi sisa panen sebelumnya yang disebut sebagai pupuk hijau (green manure). Pengolahan pertama ini bertujuan untuk membalik tanah sehingga pupuk hijau terkubur tanah dan membusuk di dalamnya. Pembajakan pertama dilakukan dalam kondisi lahan yang kering atau sedikit diairi. 
Pengolahan tanah kedua adalah pembajakan kembali dengan kondisi lahan yang sama setelah 15-20 hari sejak pembajakan pertama. Pembajakan kedua ini bertujuan untuk menyempurnakan fermentasi dan pencampuran pupuk organik (manure) dengan tanah. Sebelum pembajakan pertama atau kedua dapat juga ditambahkan pupuk-pupuk organik lainnya (kompos atau pupuk kandang) apabila diperlukan. Pada pengolahan tanah pertama dan kedua tersebut alat yang digunakan adalah bajak singkal (Sugiyanta \& Aziz, 2016).

Berikutnya adalah pengolahan tanah ketiga yang dilakukan dalam kondisi lahan yang tergenangi. Agar benih dapat tumbuh dengan baik serta irigasi dan drainase lahan dapat berlangsung dengan baik pula, pada pengolahan tanah ketiga sebaiknya juga mencakup proses pelumpuran (paddling) dan perataan (leveling) lahan. Alat yang digunakan pada proses pengolahan tanah ketiga ini adalah rotary atau glebeg. Untuk lahan yang telah siap atau lahan yang tidak menggunakan tanaman penutup (cover crop atau green manure), umumnya pengolahan lahan cukup dilakukan dua kali saja, yaitu pengolahan pertama dengan menggunakan bajak lalu pengolahan kedua dengan rotary atau glebeg. Peralatan mekanis dapat digunakan dalam penyiapan lahan guna meningkatkan kapasitas dan produktivitas, sepanjang tidak bertentangan dengan prinsip-prinsip pertanian organik. Untuk kondisi umum sawah beririgasi di Indonesia, penyiapan lahan dapat dilakukan dengan menggunakan traktor tangan dengan implemen bajak singkal dan rotary atau glebeg (Sugiyanta \& Aziz, 2016).

Benih yang akan digunakan pada budidaya padi organik dianjurkan benih yang diperbanyak dalam sistem pertanian organik, menghindari benih hasil rekayasa genetika, benih diseleksi dengan larutan garam untuk memisahkan benih yang bernas dengan yang hampa atau tidak mengisi penuh. Untuk mencegah hama penyakit yang terbawa oleh benih dengan cara diberi perlakuan dengan merendam air panas $\left(60^{\circ} \mathrm{C}\right)$ selama 6 menit 30 detik (Sugiyanta \& Aziz, 2016).

Bibit siap salur yang sehat dapat dihasilkan dari benih bermutu dan cara serta pemeliharaan dalam masa persemaian yang baik. Untuk sistem SRI (System of Rice Intensification) bibit dipindahkan ke lapangan pada saat berumur 10-14 hari setelah sebar. Benih bermutu dalam arti memiliki kemurnian varietas 100\%, daya kecambah > 98\%, kadar air $14 \%$ dan kadar kotoran < 2\%. Benih berasal dari seleksi pertanaman yang dibudidayakan secara organik menjadi syarat penting. Lahan pembibitan disiapkan dengan aplikasi pupuk kandang minimal sebulan sebelum sebar dan dibuat saluran yang memadai untuk menjamin kecukupan air ataupun mengendalikan hama keong emas. Selama masa pembibitan tidak dilakukan aplikasi pupuk maupun pestisida sintetis (Sugiyanta \& Aziz, 2016).

Teknologi pemupukan pada produksi padi organik menurut Sugiyanta \& Aziz (2016) adalah sebagai berikut:

1. Pupuk organik seperti pupuk kandang yang sudah matang atau kompos diaplikasikan di lahan dengan cara ditebar setelah penggaruan I. Dosis pupuk organik yang diberikan pada musim tanam (MT) I dan MT II sekitar 20 ton/ha dan ditambah 2 ton abu sekam/ha. Pada MT berikutnya cukup diberikan 10 ton pupuk kandang ha-1. 
2. Sebagai tambahan dapat diaplikasikan teh kompos atau pupuk kandang, yaitu pupuk kandang dilarutkan dalam air. Caranya dengan memasukkan pupuk kandang hingga setengah wadah, kemudian tambahkan air hingga mencapai permukaan wadah (konsentrasi 1:2 v/v). Setelah 1 minggu, air disaring untuk disemprotkan pada tanah dan tanaman atau disiramkan pada barisan tanaman. Setelah itu, ambil larutan pupuk kandang sebanyak $1 \mathrm{~L}$ untuk dilarutkan dengan $10 \mathrm{~L}$ air.

3. Larutan pupuk tersebut dimasukkan ke dalam knapsack sprayer, kemudian disemprotkan ke tanaman padi sawah.

4. Jerami dan pupuk kandang merupakan sumber kalium yang baik.

5. Sebagai tambahan juga dapat diberikan pupuk hayati (mikro organisme lokal/MOL) yang dapat dibuat sendiri oleh petani

6. Tidak dibolehkan mengaplikasikan zat pengatur tumbuh sintetis seperti auksin, giberelin maupun sitokinin.

Perkembangan pertanian organik diikuti dengan pertambahan jumlah produsen pupuk dan pestisida organik. Umumnya produksi pupuk organik dalam bentuk cair dan padat selain dalam bentuk media tanam dan kompos. Para produsen pupuk dan pestisida organik membentuk suatu asosiasi yang dikenal sebagai Asosiasi Pupuk Organik Indonesia (APOI) (Organic Institute et al., 2020).

Fluktuasi jumlah lahan pertanian organik sangat dipengaruhi oleh keberlanjutan sertifikasi organik dari lahan. Umumnya di daerah banyak sekali sertifikasi organik yang disubsidi oleh pemerintah daerah sehingga ada masa dimana lahan tersertifikasi tinggi dan rendah. Mahalnya biaya sertifikasi ini menjadi tantangan bagi keberlanjutan dari pertanian organik utamanya bagi kelompok tani (Organic Institute et al., 2020).

Tabel 2. Lembaga Sertifikasi Organik Indonesia

\begin{tabular}{|c|c|c|}
\hline No. Akreditasi & Nama Lembaga Sertifikasi & Alamat \\
\hline LSO-001-IDN & $\begin{array}{l}\text { PT Sucofindo (Persero) SBU Sertifikasi dan } \\
\text { Eco Framework }\end{array}$ & $\begin{array}{l}\text { Graha Sucofindo Lt. B1 Jalan Raya Pasar Minggu } \\
\text { Kav. } 34 \text { Jakarta } 12780\end{array}$ \\
\hline LSO-002-IDN & PT Mutuagung Lestari & Raya Bogor No. 19 KM 33,5 Cimanggis Depok \\
\hline LSO-003-IDN & INOFICE & Jalan Tentara Pelajar No. BB 4, Bogor \\
\hline LSO-004-IDN & $\begin{array}{l}\text { Dinas Tanaman Pangan, Hortikultura dan } \\
\text { Perkebunan Provinsi Sumatera Barat }\end{array}$ & Jalan Raden Saleh No. 4A, Padang, Sumatera Barat \\
\hline LSO-005-IDN & LeSOS & Dsn. Biting, Ds. Seloliman, Trawas, Mojokerto \\
\hline LSO-006-IDN & BIOCert Indonesia & $\begin{array}{l}\text { Jalan Perdana Raya, Ruko Cimanggu Residence } \\
\text { Blok A1, Budi Agung, Tanah Sareal, Bogor }\end{array}$ \\
\hline LSO-008-IDN & $\begin{array}{l}\text { Sustainable Development Services (SDS) } \\
\text { Indonesia }\end{array}$ & Jalan Srikoyo No. 117, Krajan, Kec. Patrang \\
\hline LSO-009-IDN & PT Icert Agritama Internasional & $\begin{array}{l}\text { Ruko Hollywood Blok F1, Jalan Pangeran Sogiri, } \\
\text { Tanah Baru, Bogor } 16154\end{array}$ \\
\hline LSO-010-IDN & PT PCU Indonesia & $\begin{array}{l}\text { Gedung AD Premier Lt. } 8 \text { Unit 5-6, Jalan TB } \\
\text { Simatupang No. 5, Ragunan, Jakarta Selatan }\end{array}$ \\
\hline
\end{tabular}

Sumber: kan.or.id 2021 
Biaya sertifikasi menyebabkan harga produk pangan organik semakin tinggi. Harga tersebut berpengaruh pada segmen pasar. Apabila produk ingin menjangkau masyarakat seharusnya biaya sertifikasi bisa lebih rendah.

Biaya sertifikasi oleh lembaga sertifikasi meliputi registrasi (pendaftaran awal), inspeksi, kemudian sertifikasi sendiri. Inspeksi ini merupakan komponen terbesar dalam sertifikasi, yang meliputi biaya persiapan inspeksi, inspeksi lapangan dan pembuatan laporan inspeksi. Hal ini berbeda dengan sistem penjaminan partisipatif yang oleh AOI (Aliansi Organis Indonesia) disebut juga penjaminan berbasis komunitas, karena praktik penjaminannya dilakukan bersama antara pihak yang terkait produksi dan konsumsi produk organik. Seluruh proses dalam penjaminan ini dilakukan bersama dalam kelompok komunitas tersebut, sehingga biaya-biaya terkait inspeksi dan lain-lain yang melibatkan pihak luar bisa ditekan (Wibowo \& Husnain, 2015).

\section{Niat Pembelian}

Penentu niat dan perilaku terdiri atas tiga dimensi menurut Ajzen (2005) dalam Theory of Planned Behavior atau model TPB, yaitu sikap, norma subjektif dan kontrol perilaku. Model ini sangat populer dan dirujuk untuk penelitian yang berkaitan dengan konsumen.

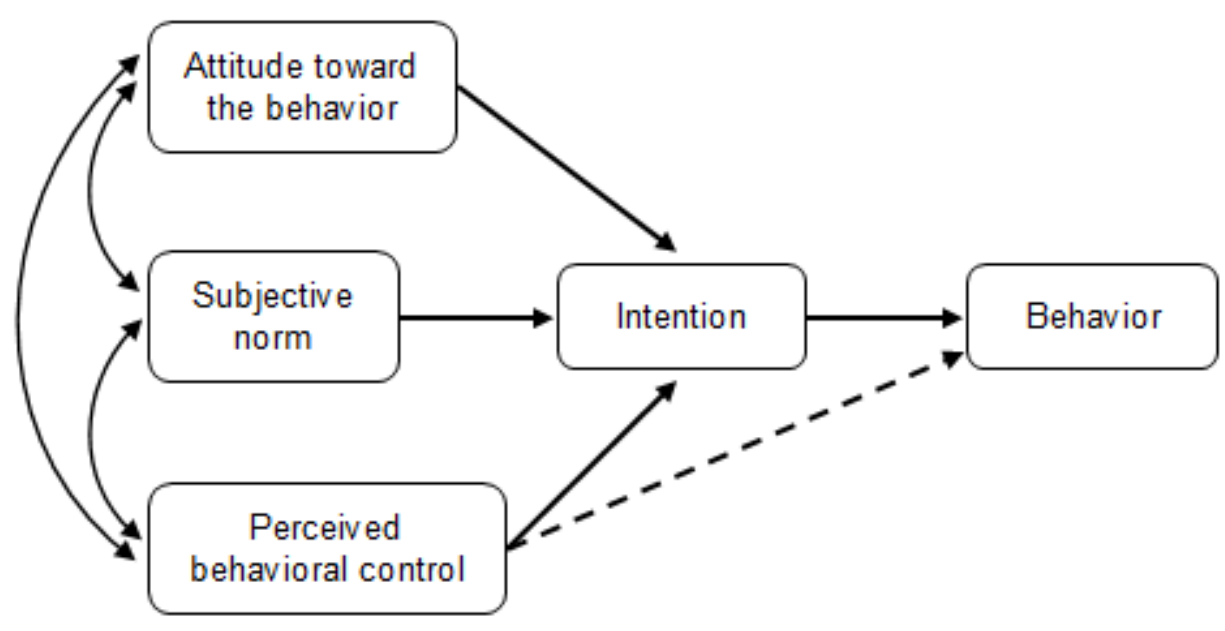

Gambar 2. Theory of Planned Behavior

Sikap digambarkan sebagai keyakinan individu secara subjektif berdasarkan evaluasinya terhadap perilaku apakah menguntungkan dan bermanfaat bagi dirinya atau sebaliknya. Pengukuran sikap yang paling populer digunakan oleh para peneliti konsumen adalah Model Multiatribut Sikap dari Fishbein. Ilustrasi sikap misalnya sikap konsumen terhadap perilaku konsumsi produk pangan organik dipersepsikan lebih menyehatkan. Pernyataan tersebut bersifat objektif. Pemahaman ini dapat diperoleh individu berdasarkan pengalaman langsung atau dapat juga dari cerita dan pengalaman orang lain. Seberapa kuat keyakinan individu terhadap konsumsi produk pangan organik dalam menyehatkan tubuh bersifat subjektif. Berdasarkan evaluasi yang dilakukan individu selama mengonsumsi produk tersebut menghasilkan perasaan puas dan senang. Perasaan puas dan senang merupakan perasaan subjektif individu yang sangat spesifik, 
dapat berbeda dengan yang dirasakan orang lain karena sudah ada pengaruh harapan, dalam hal ini makanan sehat. Apabila hasil evaluasinya tidak sesuai dengan keyakinannya maka ekspresi perasaannya akan berbeda (Ramdhani, 2016).

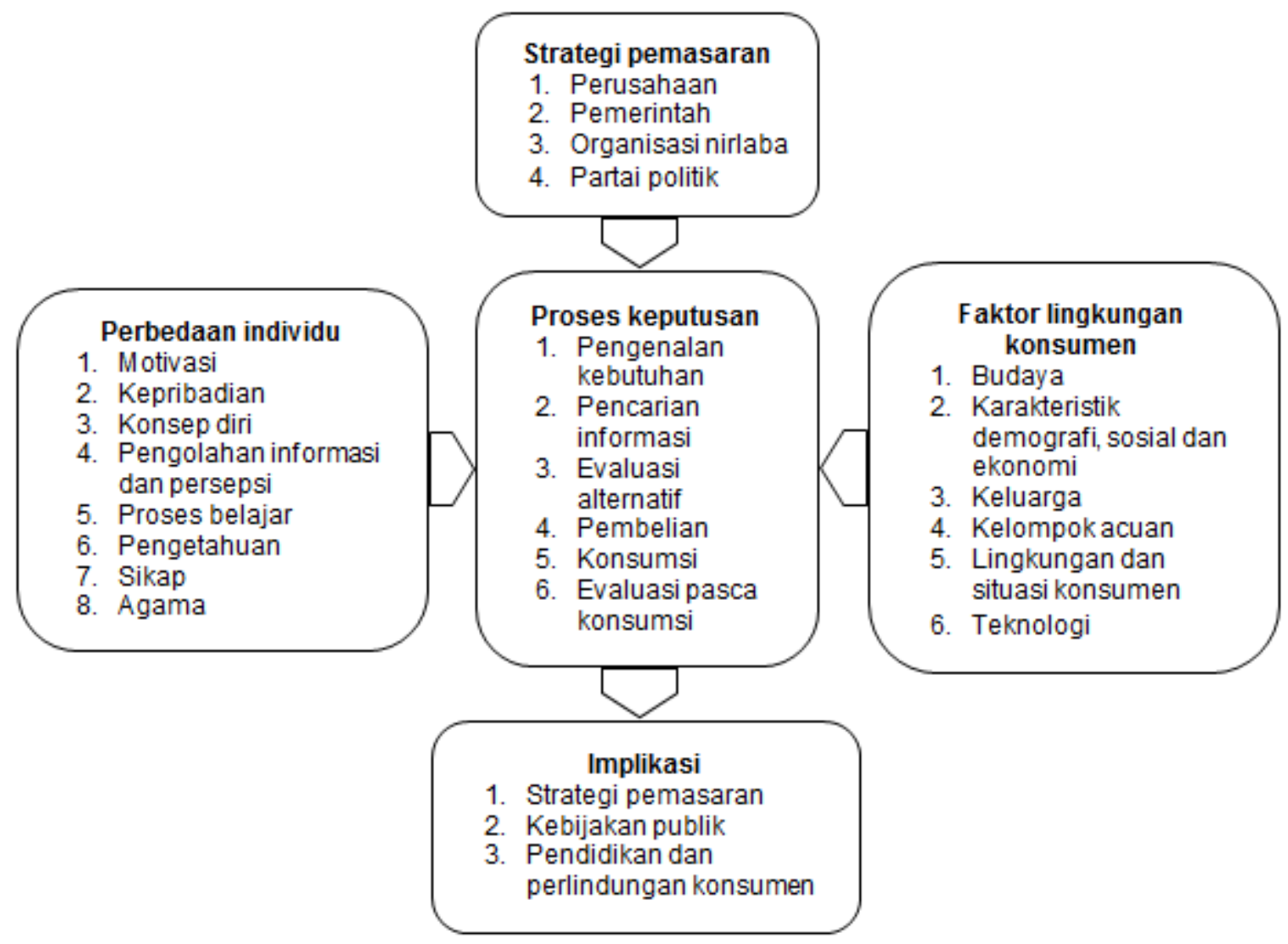

Gambar 3. Model Keputusan Konsumen

Norma subjektif juga merupakan keyakinan individu, namun diperoleh dari orang lain yang berpengaruh terhadap atau berhubungan dengan individu tersebut. Word of mouth ikut memengaruhi norma subjektif karena ada kemungkinan individu dan orang lain melakukan komunikasi dua arah (Ramdhani, 2016).

Kontrol perilaku berada di dalam diri individu, yaitu keyakinan apakah bisa melakukannya atau tidak. Keyakinan kontrol akan semakin tinggi atau kuat apabila didukung oleh ketersediaan sumberdaya dan kesempatan yang dimiliki (Ramdhani, 2016).

Selain dibentuk oleh tiga dimensi tersebut, Sumarwan (2011) melengkapi faktor-faktor yang terlibat dalam keputusan konsumen. Faktor-faktor yang dimaksud dikelompokkan dan terdiri atas perbedaan individu, lingkungan konsumen dan strategi pemasaran.

\section{Faktor-Faktor yang Memengaruhi Niat Pembelian Produk Pangan Organik}

Niat pembelian dipengaruhi oleh banyak faktor, baik dari eksternal maupun internal. Pembelian produk pangan organik tidak bisa disamakan dengan pembelian produk pangan seperti pada umumnya. 


\section{Harga}

Melalui telaah beragam jurnal telah ditemukan bahwa harga atau biaya menjadi faktor yang paling sering digunakan. Beberapa temuan mengungkapkan jika harga terjangkau mampu menarik minat beli konsumen terhadap produk pangan organik (Jitrawang \& Krairit, 2019) (Sutarni et al., 2018) (Muzayanah et al., 2015) (Suardika et al., 2014) (Kavaliauskè \& Ubartaitè, 2014), tetapi temuan yang lain berbeda, yaitu harga premium atau lebih tinggi akan membuat konsumen semakin percaya terhadap produk pangan organik sehingga mendorong mereka untuk membeli (Melovic et al., 2020) (Abadi \& Herwin, 2019) (Widyastuti, 2018) (Singh \& Verma, 2017) (Novandari, 2011) (Junaedi, 2005) (Agustina, 2004).

Setiap harga yang melekat pada produk dapat mencerminkan kualitas produk itu sendiri. Harga untuk jenis produk-produk tertentu bukan hanya berarti besaran uang yang dikeluarkan, tetapi kualitas yang sangat prima dari produk tersebut dan bahkan mempunyai arti yang lebih bagi pemilik produk tersebut (Muliasari, 2016). Menurut hasil penelitian (Hendrani et al., 2014) produsen menerapkan harga yang berbeda di tempat penjualan yang berbeda juga.

\section{Motivasi Kesehatan}

Selain faktor harga, konsumen produk pangan organik sebelumnya memiliki motivasi kesehatan. Mereka menginginkan produk yang lebih sehat diantara produk pangan. Motivasi kesehatan belum dimiliki oleh semua konsumen produk pangan, karena pada dasarnya kebutuhan konsumen berbeda-beda. Motivasi konsumen berada di tahap pengenalan kebutuhan dalam proses keputusan pembelian (Kotler \& Keller, 2009). Ada yang membeli produk pangan dengan motivasi kebutuhan pokok, namun ada juga yang menambahkan motivasi kesehatan. Mungkin ada juga yang motivasinya naik turun, mengingat produk pangan organik belum banyak ditemui. Motivasi kesehatan tidak harus dinyatakan langsung oleh konsumen, tetapi bisa diuraikan menjadi beberapa pernyataan yang mengacu pada definisi organik, diantaranya : bebas pestisida sintetis, bebas GMO (Genetically Modified Organism), ramah lingkungan (David \& Ardiansyah, 2017).

Motivasi muncul karena adanya kebutuhan yang dirasakan oleh konsumen. Kebutuhan sendiri muncul karena konsumen merasakan ketidaknyamanan (state of tension) antara yang seharusnya dirasakan dan yang sesungguhnya dirasakan. Kebutuhan yang dirasakan tersebut mendorong seseorang untuk melakukan tindakan memenuhi kebutuhan tersebut. Kebutuhan yang dirasakan konsumen (felt need) bisa dimunculkan oleh faktor diri konsumen sendiri (fisiologis), misalnya rasa lapar dan haus. Kebutuhan juga bisa dimunculkan oleh faktor luar konsumen, misalnya aroma makanan yang datang dari restoran sehingga konsumen terangsang ingin makan. Iklan dan komunikasi pemasaran lainnya bisa membangkitkan kebutuhan yang dirasakan oleh konsumen (Sumarwan, 2011).

\section{Produk}

Konsumen pangan yang memiliki motivasi kesehatan tentu akan memilih produk pangan yang berkualitas tinggi, bergizi dan menyehatkan seperti produk pangan organik 
karena produk tersebut memang dikhususkan bagi konsumen yang ingin sehat. Beberapa jurnal menyebutkan faktor produk memengaruhi niat pembelian produk pangan organik (Abadi \& Herwin, 2019) (Jitrawang \& Krairit, 2019) (Sutarni et al., 2018) (Widyastuti, 2018) (Aufanada et al., 2017) (Setiawan et al., 2016) (Risyamuka \& Mandala, 2015) (Kavaliauskė \& Ubartaité, 2014) (Suardika et al., 2014) (Chakrabarti, 2010) (Agustina, 2004). Produk harus meyakinkan konsumen untuk dibeli, yang artinya pencantuman label atau logo organik menjadi sangat penting. Produk yang mengutamakan manfaat dan mampu memberikan manfaat tambahan yang dibutuhkan konsumen akan masuk dalam kriteria evaluasi (Muliasari, 2016).

Solomon (2007) dalam Sumarwan (2011) menyatakan bahwa kegiatan konsumsi berhubungan erat dengan konsep diri. Model Self Image Congruence mengemukakan bahwa konsumen akan menggunakan produk yang memiliki atribut yang sesuai atau dapat mendukung konsep dirinya. Proses keputusan konsumen untuk membeli produk yang sesuai dengan konsep dirinya dilandasi oleh proses berpikir kognitif (terpola).

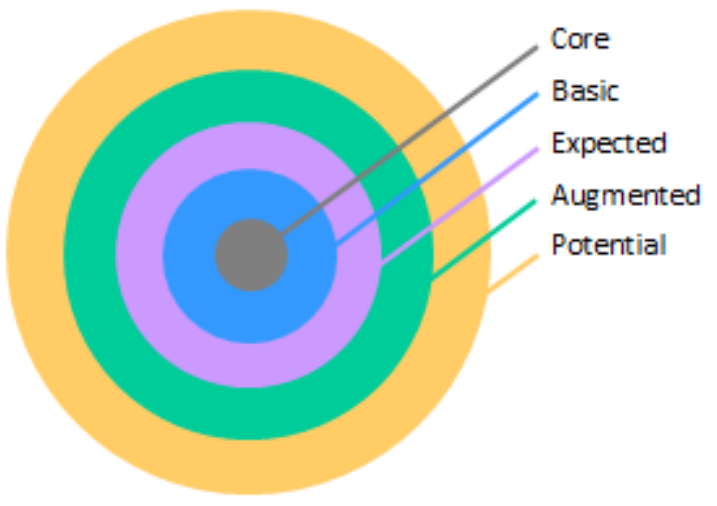

Gambar 4. Tingkatan Produk

Produk dapat dibagi menjadi lima tingkatan (Kotler dan Armstrong (2008), yaitu core benefit, basic product, expected product, augmented product dan potential product. Core benefit yaitu manfaat dasar dari suatu produk yang dibutuhkan oleh konsumen. Basic product adalah ciri atau rupa dasar dari suatu produk yang dapat dirasakan oleh panca indera. Expected product yaitu serangkaian atribut-atribut produk dan kondisi-kondisi yang layak untuk diharapkan oleh konsumen pada saat membeli suatu produk. Augmented product adalah berbagai atribut produk yang dilengkapi atau ditambahkan berbagai manfaat dan layanan sehingga sehingga dapat memberikan tambahan kepuasan dan juga dapat dibedakan dengan produk pesaing. Potential product yaitu berbagai tambahan dan perubahan yang mungkin dikembangkan untuk suatu produk di masa depan.

\section{Sikap}

Sikap terhadap produk pangan organik memengaruhi niat pembelian (Ekawati, 2020) (Manalu et al., 2020) (Melovic et al., 2020) (Jitrawang \& Krairit, 2019) (Pandey et al., 2019) (Wang et al., 2019) (Asif et al., 2018) (Chu, 2018) (Muzayanah et al., 2015) (Suardika et al., 2014). Sikap dianggap memiliki tiga unsur : (1) kognitif atau pengetahuan, (2) afektif atau emosi, perasaan, (3) konatif atau tindakan. Sikap merupakan ungkapan perasaan konsumen tentang suatu objek apakah disukai atau tidak. Sikap juga bisa 
menggambarkan kepercayaan konsumen terhadap berbagai atribut dan manfaat dari objek tersebut (Sumarwan, 2011). Sikap konsumen terhadap produk bisa diukur melalui tingkat kepentingan atribut-atribut yang seharusnya dimiliki produk dan tingkat evaluasinya terhadap atribut-atribut tersebut. Pengukuran tersebut bisa dilakukan apabila seseorang pernah mengonsumsi produk organik. Namun apabila seseorang belum pernah mengonsumsi produk organik, kecenderungan sikapnya bisa dianalisis dari faktor internal (keyakinan dan emosi) dan eksternal yang memengaruhi.

Berbagai faktor yang memengaruhi pembentukan sikap antara lain pengalaman pribadi, kebudayaan, orang lain yang dianggap penting (significant other), media massa, lembaga pendidikan atau lembaga agama dan faktor emosi dalam diri individu (Azwar, 1988 dalam Zuchdi, 1995). Empat fungsi sikap yaitu : (1) fungsi utilitarian, (2) fungsi mempertahankan ego, (3) fungsi ekspresi nilai, (4) fungsi pengetahuan (Sumarwan, 2011).

Fungsi utilitarian yang dimaksud adalah jika seseorang menyatakan sikapnya terhadap suatu objek atau produk karena ingin memeroleh manfaat dari produk (rewards) tersebut atau menghindari risiko dari produk (punishment). Manfaat produk yang dirasakan konsumen menyebabkan konsumen menyukai produk tersebut. Seseorang menyukai produk pangan organik karena bermanfaat bagi kesehatan.

Fungsi mempertahankan ego artinya sikap berfungsi untuk melindungi seseorang (citra diri-self images) dari keraguan yang muncul dari dalam dirinya sendiri atau dari faktor luar yang mungkin menjadi ancaman bagi dirinya. Sikap tersebut berfungsi untuk meningkatkan rasa aman dari ancaman yang datang dan menghilangkan keraguan yang ada dalam diri konsumen. Sikap akan menimbulkan kepercayaan diri yang lebih baik untuk meningkatkan citra diri dan mengatasi ancaman dari luar. Seseorang selalu mengonsumsi produk pangan organik karena khawatir dan takut dengan kandungan bahan kimia sintetis.

Fungsi ekspresi nilai untuk menyatakan nilai-nilai, gaya hidup dan identitas sosial dari seseorang. Sikap akan menggambarkan minat, hobi, kegiatan dan opini dari seorang konsumen. Produk pangan organik mengekspresikan nilai-nilai kesehatan.

Fungsi pengetahuan adalah salah satu karakter konsumen yang penting karena selalu ingin mengetahui banyak hal, merupakan kebutuhan konsumen. Pengetahuan yang baik mengenai suatu produk sering kali mendorong seseorang untuk menyukai produk tersebut. Oleh karena itu sikap positif terhadap suatu produk sering kali mencerminkan pengetahuan konsumen terhadap suatu produk. Konsumen menyukai produk pangan organik karena mengetahui dengan baik bahwa produk tersebut memiliki manfaat bagi kesehatan. Peningkatan pengetahuan konsumen diharapkan dapat meningkatkan konsumsi terhadap produk pangan organik.

\section{Tempat atau Distribusi}

Distribusi yang aktif akan memengaruhi niat pembelian produk pangan organik (Melovic et al., 2020) (Jitrawang \& Krairit, 2019) (Sutarni et al., 2018) (Singh \& Verma, 2017) (Risyamuka \& Mandala, 2015) (Kavaliauskè \& Ubartaitè, 2014) (Chakrabarti, 2010). Apabila produk sering terlihat di berbagai tempat, ketersediaan selalu ada, mudah ditemukan, dekat untuk dijangkau tentu membuat konsumen tertarik untuk membeli. 
Menurut teori manajemen pemasaran pada umumnya, tempat menjual berpengaruh terhadap pembelian konsumen. Tempat penjualan atau lokasi termasuk lingkungan fisik konsumen.

Akses konsumen terhadap produk organik menjadi hal penting dalam melihat pola distribusi produk organik. Diketahui bahwa cara belanja yang dilakukan konsumen organik melalui gabungan cara daring dan langsung hampir mencapai 50\%, cara belanja offline terutama bagi yang tinggal di perkotaan yaitu belanja di supermarket, toko khusus organik, melalui komunitas yang sudah mulai ada di beberapa tempat, restoran organik (Organic Institute et al., 2020).

\section{Motivasi Peduli Lingkungan}

Motivasi lain selain kesehatan adalah perhatian dan peduli dengan lingkungan. Pangan organik dianggap ramah lingkungan karena tidak menggunakan bahan-bahan kimia dalam proses produksinya. Penggunaan bahan-bahan kimia berlebihan pada produk pangan tidak dianjurkan karena dapat merusak kesuburan tanah dan keracunan bagi manusia. Ada konsumen yang membeli produk pangan organik karena dua motivasi tersebut, namun ada juga yang hanya fokus pada motivasi lingkungan atau kesehatan saja. Hasil dari penelitian di Selandia Baru menyarankan bahwa sebagian besar konsumen dipengaruhi oleh motivasi kesehatan dan lingkungan, sedangkan di Denmark niat pembelian produk organik sangat dipengaruhi oleh motivasi lingkungan (Mohamad Salleh et al., 2010).

Menurut teori Maslow atau Hierarki Kebutuhan (Maslow's Hierarchy of Needs), manusia berusaha memenuhi kebutuhan tingkat rendahnya terlebih dahulu sebelum memenuhi kebutuhan yang lebih tinggi. Konsumen yang telah bisa memenuhi kebutuhan dasarnya, maka kebutuhan lainnya yang lebih tinggi biasanya muncul dan begitu seterusnya. Kebutuhan fisiologis adalah kebutuhan dasar manusia, yaitu kebutuhan tubuh manusia untuk mempertahankan hidup. Kebutuhan rasa aman adalah kebutuhan tingkat kedua setelah kebutuhan dasar. Ini merupakan kebutuhan perlindungan bagi fisik manusia. Setelah kebutuhan dasar dan rasa aman terpenuhi, manusia membutuhkan rasa cinta dari orang lain, rasa memiliki dan dimiliki serta diterima oleh orang-orang sekelilingnya. Kebutuhan ego atau esteem adalah kebutuhan tingkat keempat, yaitu kebutuhan untuk berprestasi sehingga mencapai derajat yang lebih tinggi dari yang lainnya. Manusia memiliki ego yang kuat untuk bisa mencapai yang lebih baik untuk dirinya maupun lebih baik dari orang lain. Derajat tertinggi atau kelima dari kebutuhan adalah keinginan dari seorang individu untuk menjadikan dirinya sebagai orang terbaik sesuai dengan potensi dan kemampuan yang dimilikinya. Kebutuhan aktualisasi diri juga menggambarkan keinginan seseorang untuk mengetahui, memahami dan membentuk suatu sistem nilai, sehingga bisa memengaruhi orang lain. Kebutuhan aktualisasi diri adalah keinginan untuk bisa menyampaikan ide, gagasan dan sistem nilai yang diyakininya kepada orang lain. 


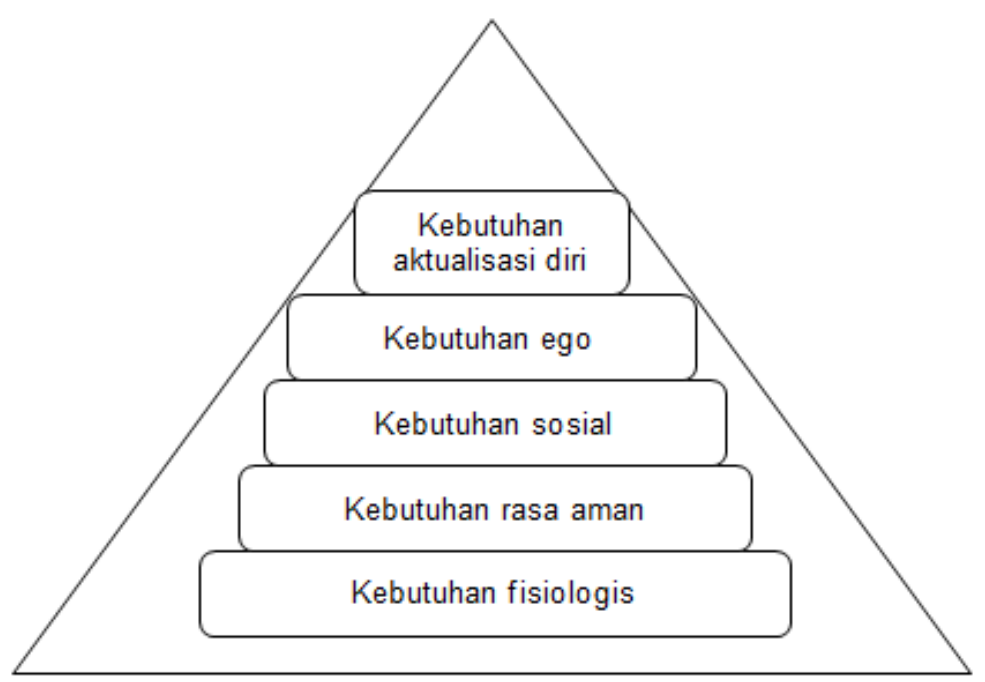

Gambar 5. Model Hierarki Kebutuhan Maslow

Apabila produk pangan organik dikaitkan dengan teori Maslow, maka bisa saja berada di tingkat kelima. Kebutuhan fisiologis tentu terlewati. Kemudian di tingkatan kedua, konsumen mengharapkan makanan yang aman dan produk pangan organik termasuk di dalamnya. Dukungan dari orang-orang di sekitar dibutuhkan konsumen untuk memenuhi kebutuhan sosialnya. Setelah mendapatkan dukungan, konsumen akan semakin mengonsumsi produk pangan organik lebih banyak atau beragam dan lebih sering untuk menjadi lebih baik dari orang lain. Jika sudah loyal, konsumen bisa memengaruhi sekitarnya.

\section{Norma Subjektif}

Norma subjektif berkaitan dengan pendapat orang lain. Menurut (Singh \& Verma, 2017) mengutip dari (Finlay et al., 1999) biasanya persepsi seseorang mengacu pada apa yang dipercaya oleh orang lain sehingga seseorang harus melakukannya juga. Tekanan dari rekan bisa memengaruhi niat pembelian seseorang, namun tergantung budaya di tempat tinggal (Jitrawang \& Krairit, 2019). Apabila seseorang memiliki kepribadian yang dekat dengan lingkungan sosial maka bisa diduga pengaruh lingkungan sosial menjadi sangat kuat terhadap orang tersebut. Pengaruh sosial akan menjadi lemah apabila seseorang cenderung mengabaikan lingkungan sosialnya atau individualis.

Hubungan antara individu dengan orang lain dapat dipersepsikan bersifat horizontal atau vertikal. Hubungan horizontal adalah hubungan yang terjadi antara dua pihak dengan posisi yang sama, misalnya teman kerja. Hubungan vertikal digambarkan oleh adanya salah satu pihak yang lebih tinggi atau lebih menentukan daripada pihak lain (Ramdhani, 2016).

Pengaruh normatif adalah pengaruh dari kelompok acuan terhadap seseorang melalui norma-norma sosial yang harus dipatuhi dan diikuti. Pengaruh normatif akan semakin kuat terhadap seseorang untuk mengikuti kelompok acuan jika ada (1) tekanan kuat untuk mematuhi norma-norma yang ada, (2) penerimaan sosial sebagai motivasi kuat dan (3) produk dan jasa yang dibeli akan terlihat sebagai simbol dari norma sosial. Seorang konsumen cenderung akan mengikuti apa yang dikatakan atau disarankan oleh 
kelompok acuan jika ada tekanan kuat untuk mengikuti norma-norma yang ada. Pengaruh semakin kuat jika ada sanksi sosial bagi konsumen yang tidak mengikuti saran dari kelompok acuan. Seorang konsumen mungkin memiliki motivasi kuat untuk mengikuti perilaku kelompok acuannya karena adanya keinginan untuk diterima oleh kelompok acuan tersebut. Motivasi untuk mematuhi norma seringkali tidak cukup kuat untuk memengaruhi perilaku seseorang, kecuali jika produk dan jasa yang akan dibeli menggambarkan publicly conspicuous (produk yang terlihat pemakaiannya oleh orang lain) dalam pembelian dan penggunaannya. Jika produk dan jasa yang dibeli akan terlihat oleh publik atau orang lain dalam pemakaiannya, maka konsumen akan berusaha mematuhi norma-norma yang diarahkan oleh kelompok acuan tersebut, karena produk dan jasa yang dibeli akan menggambarkan citra diri konsumen tersebut (Sumarwan, 2011).

\section{Simpulan}

Faktor-faktor yang umumnya memengaruhi niat pembelian produk pangan organik terdiri atas harga, motivasi sehat, karakteristik produk, sikap, distribusi, kepedulian pada lingkungan dan norma subjektif. Harga dapat disesuaikan dengan pendapatan atau daya beli masyarakat di sekitar tempat penjualan. Penyesuaian ini tentu akan menghasilkan harga jual yang berbeda. Motivasi sehat biasanya dimiliki oleh konsumen yang hobi berolahraga. Karakteristik produk yang diinginkan dari produk organik tentunya label, kesegaran dan menarik. Sikap positif konsumen terhadap produk organik merupakan akumulasi dari faktor eksternal dan internal. Faktor internal yang dimaksud adalah motivasi sehat dan kepedulian pada lingkungan, sedangkan faktor eksternal adalah norma subjektif. Pendistribusian secara luas juga dapat mendekatkan dan memengaruhi konsumen.

Produsen produk organik disarankan melakukan pengkelasan (grading) apabila harga produk menyesuaikan daya beli masyarakat di sekitar tempat penjualan. Untuk meningkatkan penjualan, distribusi produk harus menjangkau banyak wilayah supaya dekat dengan konsumen dan memilih wilayah yang konsumennya sadar kesehatan dan peduli terhadap lingkungan, seperti di lapangan olahraga dan tempat berpolusi.

Penelitian mendatang direkomendasikan fokus pada salah satu produk pangan organik yang umum dijual di pasar, karena tentu saja produsennya juga cukup banyak sehingga hasil penelitian lebih dibutuhkan.

\section{Daftar Pustaka}

Abadi, F., \& Herwin, H. (2019). Pengaruh Harga, Kualitas Produk Dan Kualitas Pelayanan Terhadap Keputusan Pembelian Beras Organik Di Jakarta. Jurnal Riset Manajemen Dan Bisnis (JRMB) Fakultas Ekonomi UNIAT, 4(1), 1-8. https://doi.org/10.36226/jrmb.v4i1.235

Agustina, T. (2004). Analisis perilaku konsumen beras organik di kabupaten jember. Titin Agustina, vol 5 no 3, 15-21. 
Ajzen, I. (2005). Attitudes, Personality and Behavior 2nd Edition. Berkshire, UK: Open University Press-McGraw Hill Education.

Asif, M., Xuhui, W., Nasiri, A., \& Ayyub, S. (2018). Determinant factors influencing organic food purchase intention and the moderating role of awareness: A comparative analysis. Food Quality and Preference, 63, 144-150. https://doi.org/10.1016/j.foodqual.2017.08.006

Aufanada, V., Ekowati, T., \& Prastiwi, W. D. (2017). Kesediaan Membayar Produk Sayuran Organik di Pasar Modern Jakarta Selatan. AGRARIS: Journal of Agribusiness and Rural Development Research, 3(2), 67-75.

Balai Pengkajian Teknologi Pertanian Sulawesi Utara. (2016). Pertanian Organik Penting untuk Masa Depan Bangsa. Https://Sulut.Litbang.Pertanian.Go.Id/. https://sulut.litbang.pertanian.go.id/index.php/info-teknologi/hortikultura/106-infoteknologi4 /717-pertanian-organik-penting-untuk-masa-depan-bangsa

Chakrabarti, S. (2010). Factors influencing organic food purchase in India - expert survey insights. British Food Journal, 112(8), 902-915. https://doi.org/10.1108/00070701011067497

Chu, K. M. (2018). Mediating influences of attitude on internal and external factors influencing consumers' intention to purchase organic foods in China. Sustainability (Switzerland), 10(12), 1-15. https://doi.org/10.3390/su10124690

David, W., \& Ardiansyah. (2017). Perceptions of young consumers toward organic food in Indonesia. International Journal of Agricultural Resources, Governance and Ecology, 13(4), 315-324. https://doi.org/10.1504/IJARGE.2017.088373

Ekawati, T. (2020). Kajian faktor-faktor yang mempengaruhi niat beli produk organik. Journal of Business and Information Systems (e-ISSN: 2685-2543), 2(1), 32-45. https://doi.org/10.36067/jbis.v2i1.35

Hendrani, Y., Ph, D., Susanto, S., Suroso, D. P. C., Reg, L. R., Anna, D., \& Poerbonegoro, F. (2014). Perdagangan Produk Organik: Value Chains Dan Determinan Keputusan Konsumen Membeli Produk Organik Disusun Oleh: Lembaga Penelitian dan Pengabdian kepada Masyarakat Universitas Katolik Parahyangan.

Jitrawang, P., \& Krairit, D. (2019). Factors Influencing Purchase Intention of Organic Rice in Thailand. Journal of Food Products Marketing, 25(8), 805-828. https://doi.org/10.1080/10454446.2019.1679690

Junaedi, M. F. S. (2005). Pengaruh Kesadaran Lingkungan Pada Niat Beli Produk Hijau: Studi Perilaku Konsumen Berwawasan Lingkungan. Benefit: Jurnal Manajemen Dan Bisnis, 9(2), 189-201.

Kavaliauskè, M., \& Ubartaitè, S. (2014). Ethical Behaviour: Factors Influencing Intention To Buy 
Organic Products in Lithuania. Economics and Management, 19(1), 72-83. https://doi.org/10.5755/j01.em.19.1.4991

Kotler, P. dan Armstrong, G. (2008). Prinsip-Prinsip Pemasaran Edisi ke-12 Jilid 1. Jakarta: Erlangga.

Kotler, P. dan Keller, KL. (2009). Manajemen Pemasaran Edisi ke-13 Jilid 1. Jakarta: Erlangga.

Manalu, V. G., Manajemen, P. S., Ekonomi, F., Kuningan, U., Kuningan, K., Produk, P., Lingkungan, R., \& Organik, P. P. (2020). Green Product Purchase Intention in Indonesia: Theory Planned. 4(2).

Melovic, B., Cirovic, D., Dudic, B., Vulic, T. B., \& Gregus, M. (2020). The analysis of marketing factors influencing consumers' preferences and acceptance of organic food products - recommendations for the optimization of the offer in a developing market. Foods, 9(3). https://doi.org/10.3390/foods9030259

Mohamad Salleh, M., Ali, S. M., Harun, E. H., Jalil, M. A., \& Shaharudin, M. R. (2010). Consumer' s Perception and Purchase Intentions Towards Organic Food Products : Exploring Attitude Among Academician. Canadian Social Science, 6(6), 119-129.

Muliasari, R. M. (2016). Pengaruh Bauran Pemasaran Terhadap Kepuasan Konsumen Roti Merek Sari Roti. Institut Pertanian Bogor.

Muzayanah, F. N., Suroso, A. I., \& Najib, M. (2015). Faktor-faktor yang Memengaruhi Resistensi Pembelian Pangan Organik dan Proses Pendidikan Konsumen. Jurnal Manajemen Dan Agribisnis, 12(3), 163-173. https://doi.org/10.17358/jma.12.3.163

Novandari, W. (2011). Analisis Motif Pembelian dan Profil Perilaku "Green Product Customer" (Studi pada Konsumen Produk Pangan Organik di Purwokerto). JEBA UNSOED : jurnal ekonomi, bisnis dan akuntansi, 13(1), 9-16. https://doi.org/10.32424/jeba.v13i1.346

Organic Institute, Yayasan Alifa \& Kombas.id. (2020). Statistik Pertanian Organik Indonesia 2019. Bogor: Aliansi Organis Indonesia.

Pandey, D., Kakkar, A., Farhan, M., \& Khan, T. A. (2019). Factors influencing organic foods purchase intention of Indian customers. Organic Agriculture, 9(4), 357-364. https://doi.org/10.1007/s13165-018-0240-z

Peraturan Menteri Pertanian Nomor 64/Permentan/OT.140/5/2013 tentang Sistem Pertanian Organik, Pasal 1 Ayat 3

Pusat Sosial Ekonomi dan Kebijakan Pertanian. (2020). Efek Positif Corona: Permintaan Sayur Organik Melonjak. Http://Pse.Litbang.Pertanian.Go.Id/. http://pse.litbang.pertanian.go.id/ind/index.php/covid-19/berita-covid19/421-efek-positif-coro na-permintaan-sayur-organik-melonjak 
Ramdhani, N. (2016). Penyusunan Alat Pengukur Berbasis Theory of Planned Behavior. Buletin Psikologi, 19(2), 55-69. https://doi.org/10.22146/bpsi.11557

Risyamuka, I. K., \& Mandala, K. (2015). Pengaruh Green Marketing terhadap Keputusan Pembelian Produk Hijau di Restoran Sari Organik Ubud. E-Jurnal Manajemen Universitas Udayana, $\quad$ 4(2). ISSN 2302-8912. Available at: https:/ojs.unud.ac.id/index.php/Manajemen/article/view/10803

Setiawan, A., Zakaria, W. A., \& Indriani, Y. (2016). perilaku Konsumen Dalam Pembelian Beras Organik Produksi Kabupaten Pringsewu. Jurnal JIIA, 4(2), 192-199.

Singh, A., \& Verma, P. (2017). Factors influencing Indian consumers' actual buying behaviour towards organic food products. Journal of Cleaner Production, 167, 473-483. https://doi.org/10.1016/j.jclepro.2017.08.106

Suardika, M. P., Ambarawati, G. A. A., \& Sukaatmadja, P. (2014). Analisis perilaku konsumen terhadap keputusan pembelian sayur organik cv golden leaf farm bali. Jurnal Manajemen Agribisnis, 2(1), 1-10.

Sugiyanta \& Aziz, S. A. (2016). Beras dan Tanaman Pangan Organik Lainnya. Bogor: IPB Press.

Sumarwan, U. (2011). Perilaku Konsumen: Teori dan Penerapannya dalam Pemasaran Edisi ke-2. Bogor: Ghalia Indonesia.

Sutarni, S., Trisnanto, T. B., \& Unteawati, B. (2018). Preferensi Konsumen Terhadap Atribut Produk Sayuran Organik di Kota Bandar Lampung. Jurnal Penelitian Pertanian Terapan, 17(3), 203. https://doi.org/10.25181/jppt.v17i3.337

Syukur, M., \& Melati, M. (2016). Pengembangan Sayuran Organik. Hal 175-192 dalam Buku Pengembangan Pertanian Organik di Indonesia. IPB Press, cetakan pertama, April 2016

Wang, X., Pacho, F., Liu, J., \& Kajungiro, R. (2019). Factors influencing organic food purchase intention in Tanzania and Kenya and the moderating role of knowledge. Sustainability (Switzerland), 11(1). https://doi.org/10.3390/su11010209

Wibowo, H. \& Husnain. (2015). Sertifikasi Dan Pasar Pertanian Organik.

Widyastuti, P. (2018). Kualitas dan Harga sebagai Variabel Terpenting pada Keputusan Pembelian Sayuran Organik. Ekspektra: Jurnal Bisnis Dan Manajemen, 2(1), 17. https://doi.org/10.25139/ekt.v2i1.675

Zuchdi, D. (1995). Pembentukan Sikap. Jurnal Cakrawala Pendidikan, 3(3), 51-63. https://doi.org/10.21831/cp.v3i3.9191 